\title{
Therapeutic plasma exchange in pemphigus vulgaris: Retrospective study from a tertiary care center
}

\section{Plasmaféresis terapéutica en pénfigo vulgar: estudio retrospectivo de un centro de atención de tercer nivel}

\author{
Alba Cicero-Casarrubias ${ }^{1 *}$, Silvia Méndez-Flores ${ }^{2}$, and Judith Domínguez-Cherit ${ }^{2}$ \\ ${ }^{1}$ Department of Immunology and Rheumatology; ${ }^{2}$ Department of Dermatology. Instituto Nacional de Ciencias Médicas y Nutrición Salvador Zubirán, \\ Mexico City, Mexico
}

\begin{abstract}
Background: Pemphigus vulgaris (PV) is characterized by the presence of autoantibodies against desmoglein 1 and 3 with resulting formation of epidermal blisters. The rationale for using therapeutic plasma exchange (TPE) is the removal of pathogenic autoantibodies, this procedure is considered a third-line treatment. Objective: The objective of the study was to analyze the role of plasmapheresis in PV patients that do not respond to conventional therapy and its long-term effect of prednisone dose. Materials and methods: We performed a retrospective analysis of a case series of six PV patients who underwent TPE from December 2011 to October 2015. We recorded demographic data, pre-existing medical conditions, immunosuppressant doses taken before and after TPE, number of TPE sessions, and adverse events related to TPE. We compared the prednisone dose before TPE and 6 months later. Results: The median affected body surface area at the time of admission was 54\%. Before TPE, all the patients were receiving systemic corticosteroids (at least $1 \mathrm{mg} / \mathrm{kg} /$ day) and had received other immunosuppressants without adequate response. The median number of TPE sessions received by each patient was 3, and the median time to reepithelization after starting TPE was 10 days. No serious adverse events related to TPE were registered. At the 6-month follow-up, all the patients experienced significant reduction in the absolute prednisone dose $(p=0.0413)$, with a median reduction in prednisone dosage of $40 \mathrm{mg} /$ days. Conclusion: TPE is a safe procedure that has been proved effective in the treatment of refractory cases of $P V$, it accelerates clinical response and it can contribute in the long-term dose reduction of prednisone.
\end{abstract}

Key words: Pemphigus. Plasmapheresis. Blistering.

\section{Resumen}

Antecedentes: El pénfigo vulgar (PV) se caracteriza por la presencia de autoanticuerpos contra las desmogleínas 1 y 3 y da lugar a la formación de ampollas epidérmicas. El fundamento para usar la plasmaféresis terapéutica (PT) es retirar los autoanticuerpos patogénicos; este procedimiento se considera un tratamiento de tercera línea. Objetivo: Analizar el papel de la PT en pacientes con PV que no responden al tratamiento convencional y su efecto a largo plazo en la dosis de prednisona. Material y métodos: Análisis retrospectivo de una serie de casos de seis pacientes con PV sometidos a PT entre 2011 y 2015. Se registraron los datos demográficos, condiciones médicas, dosis de inmunosupresores iniciales y posteriores

Correspondence:

*Alba Cicero-Casarrubias

E-mail: albcicero@gmail.com

0210-5187/@ 2021 Colegio Ibero Latinoamericano de Dermatología A.C. (CILAD). Publicado por Permanyer. Este es un artículo open access bajo la licencia CC BY-NC-ND (http://creativecommons.org/licenses/by-nc-nd/4.0/).
Disponible en internet: 01-09-2021 Med Cutan Iber Lat Am. 2021;49(3):127-131

www.MedicinaCutanealLA.com 
a la PT, número de sesiones de PT y efectos adversos relacionados con la PT. Se comparó la dosis de prednisona antes de la PT y seis meses después. Resultados: La media de superficie corporal afectada fue de $54 \%$. Antes de la PT, todos los pacientes recibieron corticosteroides sistémicos (al menos $1 \mathrm{mg} / \mathrm{kg} / \mathrm{día}$ ) e inmunosupresores sin adecuada respuesta. La media de sesiones de PT por paciente fue de tres y el tiempo medio para la reepitelización fue 10 días. No se registraron efectos adversos graves relacionados con la PT. A los seis meses, todos los pacientes mostraron una reducción significati-

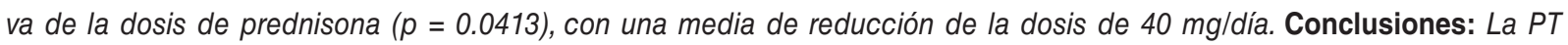
es un procedimiento seguro y efectivo en el tratamiento de casos resistentes, acelera la respuesta clínica y puede contribuir a la reducción a largo plazo de la dosis de prednisona.

Palabras clave: Pénfigo. Plasmaféresis. Ampollosas.

\section{Introduction}

Pemphigus vulgaris (PV) is characterized by the presence of autoantibodies against keratinocyte cell surface antigens (desmoglein 1 and 3 ) with resulting formation of epidermal blisters. The first-line treatments include highdose corticosteroids, rituximab, and corticosteroid-sparing agents (azathioprine and mycophenolate mofetil), and most patients improve after 1-3 months of treatment ${ }^{1}$. Nowadays, mortality of PV is approximately $6 \%$ and is mainly related to pharmacological adverse effects ${ }^{2,3}$.

Failure of therapy is defined as "failure to control disease activity (i.e. relapse/flare) with full therapeutic doses of systemic treatments"4. Current guidelines consider as the third-line or rescue treatments the use of cyclophosphamide, intravenous immunoglobulins, methotrexate, cyclosporine, immunoadsorption, and plasmapheresis ${ }^{1,5,6}$. The American Society for Apheresis guidelines recommend therapeutic plasma exchange (TPE) in severe cases of $\mathrm{PV}^{7}$. The rationale for using TPE in PV is the removal of pathogenic autoantibodies. The decision to use this treatment modality can be based in the following reasons: (a) refractory disease despite unacceptably high doses of corticosteroids, (b) severe disease that needs rapid control, (c) contraindication to certain immunosuppressives, and (d) longterm corticosteroid sparing $2,8,9$.

The objective of this study was to analyze the role of plasmapheresis in PV patients that do not respond to conventional therapy and its long-term effect of prednisone dose. We present a retrospective series of six patients treated with TPE in combination with high-dose immunosuppressive therapy.

\section{Methods}

\section{Patients}

We examined retrospectively the data of six PV patients who underwent TPE from December 2011 to
October 2015 in a tertiary care center. We reviewed the patients' charts. We recorded demographic data, pre-existing medical conditions, immunosuppressant doses taken before and after TPE, number of TPE sessions, and adverse events. The affected body surface area was based on the extent of epidermal detachment at the time of admission for TPE. Anti-desmoglein titers before TPE were available in three cases, we did not perform follow-up with antibody titers.

\section{TPE}

TPE was performed with a continuous-flow blood processor (centrifugation technique). All TPEs were administered every other day, with a replacement fluid ratio of $50 \mathrm{~mL} / \mathrm{kg}$ (human albumin $5 \%$ or hydroxyethyl starch). The number of TPE sessions performed was dependent on the patient clinical response and disease severity. Patients were considered to respond if there were no new blisters and older ones were healing. The principles outlined in the Declaration of Helsinki were followed.

\section{Statistical analysis}

Summary measures of data are expressed in medians and interquartile ranges (IQR). The prednisone dose before TPE and 6 months later was compared with the Wilcoxon signed-rank test. $p<0.05$ was considered statistically significant. All analyses were done using Stata software version 11.0 (StataCorp, TX).

\section{Results}

The median age of patients was 33.5 years (IQR 13 year), with a male: female ratio of 1:6. The median affected body surface area at the time of admission was $54 \%$ (IQR $45.75 \%$ ) and disease duration previous to TPE was 5 months (IQR 22 months). All the patients were receiving systemic corticosteroids (at least $1 \mathrm{mg} / \mathrm{kg} /$ day) and had received other immunosuppressants before 
Table 1. Patients' details and indication for therapeutic plasma exchange

\begin{tabular}{|c|c|c|c|c|c|c|c|c|c|}
\hline $\mathbf{P t}$ & $\begin{array}{c}\text { Age } \\
\text { (years) }\end{array}$ & Sex & $\begin{array}{l}\text { Comor- } \\
\text { bidities }\end{array}$ & $\begin{array}{c}\text { Affected } \\
\text { body } \\
\text { surface } \\
\text { area (\%) }\end{array}$ & $\begin{array}{l}\text { Disease } \\
\text { duration } \\
\text { before TPE } \\
\text { (months) }\end{array}$ & $\begin{array}{l}\text { Immunosuppre- } \\
\text { sants prior to } \\
\text { TPE }\end{array}$ & $\begin{array}{l}\text { Anti-Dsg1 } \\
\text { titer }\end{array}$ & $\begin{array}{l}\text { Anti-Dsg3 } \\
\text { titer }\end{array}$ & TPE indication \\
\hline 1 & 58 & $F$ & HT & 63 & 5 & $\begin{array}{l}\text { Pdn } 60 \mathrm{mg} / \text { day } \\
\text { Mpd } 1 \mathrm{~g} / \mathrm{d} \\
\text { (3 doses) } \\
\mathrm{Mp} 1 \mathrm{~g} / \mathrm{d} \\
\mathrm{Ig} 400 \mathrm{mg} / \mathrm{kg}\end{array}$ & $38.13 \mathrm{RU} / \mathrm{ml}^{*}$ & $\begin{array}{l}138.74 \\
\mathrm{RU} / \mathrm{ml}^{*}\end{array}$ & $\begin{array}{l}\text { Non-responder to drug } \\
\text { therapy, rapid control } \\
\text { and contraindication } \\
\text { for other steroid- } \\
\text { sparing medication }\end{array}$ \\
\hline 2 & 24 & $F$ & - & 90 & 6 & $\begin{array}{l}\mathrm{Pdn} 60 \mathrm{mg} / \mathrm{d} \\
\mathrm{Dp}(\text { dose NS) }\end{array}$ & NA & NA & $\begin{array}{l}\text { Non-responder to drug } \\
\text { therapy and rapid } \\
\text { control }\end{array}$ \\
\hline 3 & 28 & $F$ & - & 20 & 31 & $\begin{array}{l}\text { Pdn } 60 \mathrm{mg} / \mathrm{d} \\
\text { Aza } 150 \mathrm{mg} / \mathrm{d}\end{array}$ & NA & NA & $\begin{array}{l}\text { Non-responder to drug } \\
\text { therapy }\end{array}$ \\
\hline 4 & 45 & $\mathrm{~F}$ & - & 20 & 70 & $\begin{array}{l}\text { Pdn } 70 \mathrm{mg} / \mathrm{d} \\
\text { Aza } 100 \mathrm{mg} / \mathrm{d} \\
\text { Th } 100 \mathrm{mg} / \mathrm{d}\end{array}$ & NA & NA & $\begin{array}{l}\text { Non-responder to drug } \\
\text { therapy }\end{array}$ \\
\hline 5 & 33 & $\mathrm{M}$ & - & 75 & 9 & $\begin{array}{l}\text { Pdn } 140 \mathrm{mg} / \mathrm{d} \\
\text { Aza } 150 \mathrm{mg} / \mathrm{d} \\
\mathrm{Mp} \text { (dose NS) } \\
\mathrm{lg} 1 \mathrm{~g} / \mathrm{kg} / \mathrm{d}(3 \\
\text { doses) } \\
\text { Cp (dose NS) }\end{array}$ & $181 \mathrm{U} / \mathrm{ml}^{* *}$ & $175 \mathrm{U} / \mathrm{ml}^{* *}$ & $\begin{array}{l}\text { Non-responder to drug } \\
\text { therapy and rapid } \\
\text { control }\end{array}$ \\
\hline 6 & 34 & $\mathrm{~F}$ & - & 45 & 6 & $\begin{array}{l}\text { Pdn } 60 \mathrm{mg} \\
\text { Aza } 100 \mathrm{mg}\end{array}$ & $159 \mathrm{U} / \mathrm{ml}^{* *}$ & $63 \mathrm{U} / \mathrm{ml}^{* *}$ & $\begin{array}{l}\text { Non-responder to drug } \\
\text { therapy and rapid } \\
\text { control }\end{array}$ \\
\hline
\end{tabular}

Pt: patient; TPE: therapeutic plasma exchange; M: male; F: female; HT: hypertension; Pdn: prednisone; Mpdn: methylprednisolone; Mp: mycophenolate; Ig: immunoglobulin; Dp: dapsone; Aza: azathioprine; Th: thalidomide; Cp: cyclophosphamide; Dsg1: desmoglein 1; Dsg3: desmoglein 3; NS: non-specified; NA: not available

${ }^{*}$ Reference values: anti-Dsg1 $\leq 20 \mathrm{RU} / \mathrm{ml}$ and anti-Dsg3 $\leq 20 \mathrm{RU} / \mathrm{ml}$

${ }^{* *}$ Reference values: anti-Dsg1 $\leq 13 \mathrm{U} / \mathrm{ml}$ and anti-Dsg3 $\leq 9 \mathrm{U} / \mathrm{ml}$.

TPE without adequate response (Table 1). Patients 1, 2, and 5 were in septic shock before starting TPE.

The median number of TPE sessions received by each patient was 3 (IQR 1.75). The median time to reepithelization after starting TPE was 10 days (IQR 6 days). Five patients responded after TPE. Patient 3 achieved reepithelization while on TPE, but relapsed as soon as it was suspended, she was referred to other institution for further care.

The complications associated to therapy were the following: coagulopathy (one event), hypotension (one event), and hypocalcemia (one event). Patient 5 died secondary to septic complications, although he was in septic shock before TPE and remained in septic shock throughout the sessions.

The treatments prescribed after the last session of TPE, at 3 months and 6 months after TPE are listed in table 2. All patients received prednisone at a minimum dose of $1 \mathrm{mg} / \mathrm{kg} /$ day; four patients received combination treatment. At the 6-month follow-up, all the patients experienced significant reduction in the absolute prednisone dose $(p=0.0413)$, with a median reduction in prednisone dosage of $40 \mathrm{mg} /$ day (IQR $37.5 \mathrm{mg} /$ day).

The median time of follow-up since the TPE is 4.9 years (IQR 1.2 years), one patient was lost to follow-up. At the time of this analysis, two patients remained in complete remission and two presented minimal oral activity. Only one patient continued receiving prednisone (5 mg/day) and two azathioprine.

\section{Discussion}

At present, the first-line treatments include high-dose corticosteroids, rituximab, and corticosteroid-sparing agents (azathioprine and mycophenolate mofetil), while the third-line or rescue treatments include cyclophosphamide, immunoadsorption, intravenous immunoglobulins, methotrexate, cyclosporine, immunoadsorption, and plasmapheresis ${ }^{1,5,6}$.

The rationale for using TPE in PV is the removal of pathogenic autoantibodies ${ }^{10}$.TPE is usually combined with immunosuppressive treatment to avoid a rebound effect ${ }^{11}$. 
Table 2. Therapeutic plasma exchange indication, outcome and therapy

\begin{tabular}{|c|c|c|c|c|c|c|c|c|}
\hline $\mathbf{P t}$ & NS* & $\begin{array}{l}\text { Out- } \\
\text { come }\end{array}$ & $\begin{array}{l}\text { Time to } \\
\text { reepitheli- } \\
\text { zation (days) }\end{array}$ & $\begin{array}{l}\text { Medications } \\
\text { after TPE }\end{array}$ & $\begin{array}{l}\text { Medications } 3 \\
\text { months after } \\
\text { TPE }\end{array}$ & $\begin{array}{l}\text { Medications } 6 \\
\text { months after TPE }\end{array}$ & $\begin{array}{l}\text { Absolute pdn } \\
\text { reduction** } \\
(\mathrm{mg} / \mathrm{d})\end{array}$ & P value ${ }^{* * *}$ \\
\hline 1 & 5 & CR & 24 & $\mathrm{Pdn} 70$ mg/d & $\mathrm{Pdn} 30 \mathrm{mg} / \mathrm{d}$ & $\mathrm{Pdn} 12.5 \mathrm{mg} / \mathrm{d}$ & -47.5 & 0.0431 \\
\hline 2 & 4 & CR & 10 & $P d n 60$ mg/d & $P d n 20$ mg/d & $\begin{array}{l}\text { Pdn } 20 \text { mg/d } \\
\text { Aza } 75 \text { mg/d }\end{array}$ & -40 & \\
\hline 3 & 3 & $N R^{* * * *}$ & 7 & $\begin{array}{l}\text { Pdn } 60 \mathrm{mg} / \mathrm{d} \\
\text { Aza } 150 \mathrm{mg} / \mathrm{d}\end{array}$ & $\begin{array}{l}\text { Pdn } 60 \mathrm{mg} / \mathrm{d} \\
\text { Aza } 150 \mathrm{mg} / \mathrm{d}\end{array}$ & $\begin{array}{l}\text { Pdn } 55 \mathrm{mg} / \mathrm{d} \\
\text { Aza } 150 \mathrm{mg} / \mathrm{d}\end{array}$ & -5 & \\
\hline 4 & 3 & $\mathrm{CR}$ & 7 & 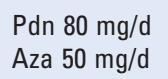 & $\begin{array}{l}\text { Pdn } 60 \mathrm{mg} / \mathrm{d} \\
\text { Aza } 150 \mathrm{mg} / \mathrm{d}\end{array}$ & $\begin{array}{l}\text { Pdn } 15 \mathrm{mg} / \mathrm{d} \\
\text { Aza } 150 \mathrm{mg} / \mathrm{d}\end{array}$ & -55 & \\
\hline 5 & 5 & CR & $-{ }^{\dagger}$ & $\mathrm{Pdn} 70$ mg/d & - & - & - & \\
\hline 6 & 3 & $\mathrm{CR}$ & 13 & $\begin{array}{l}\text { Pdn } 95 \mathrm{mg} / \mathrm{d} \\
\text { Cp } 650 \mathrm{mg} \\
\text { (single dose) }\end{array}$ & $\begin{array}{l}\text { Pdn } 90 \mathrm{mg} / \mathrm{d} \\
\text { Aza } 150 \mathrm{mg} / \mathrm{d}\end{array}$ & $\begin{array}{l}\text { Pdn } 50 \mathrm{mg} / \mathrm{d} \\
\text { Aza } 150 \mathrm{mg} / \mathrm{d}\end{array}$ & -10 & \\
\hline
\end{tabular}

* Sessions administered every 48 hours

** Amount reduced within 6 months after last TPE

*** Wilcoxon signed ranked test. A p value $<0.05$ was considered statistically significant.

**** Although patient 3 showed reepithelization at the end of TPE, blisters continued appearing afterwards.

${ }^{\dagger}$ The patient died secondary to infectious complications before complete reepithelization was achieved, although he showed remarkable skin improvement as soon as TPE was started

Pt: patient; TPE: therapeutic plasma exchange; NS: number of sessions; CR: clinical response; NR: non-responder; Pdn: prednisone; Aza: azathioprine; Cp: cyclophosphamide.

This retrospective analysis supports previous reports of the clinical benefit of TPE in combination with aggressive immunosuppression for rapid disease control and long-term prednisone dose reduction in selected cases (refractory to treatment, widespread disease, or contraindication to certain immunosuppressants) $)^{8,9,12-15}$. We found a significant reduction in prednisone dose 6 months after TPE in patients who were refractory to immunosuppressive treatment before TPE.

There is only one clinical trial that evaluates the efficacy of Guillaume et al. reported a two-armed controlled clinical trial $(n=40)$ in pemphigus patients naïve to systemic CS and immunosuppressive treatments. The goal was to compare the efficacy of prednisolone alone with prednisolone and 10 plasma exchange sessions. All patients received and initial prednisolone dose of $0.5 \mathrm{mg} / \mathrm{kg} / \mathrm{day}$ and it was adjusted according to clinical response. The authors did not find any significant difference in efficacy among both treatment arms and four patients in the $\mathrm{PE}$ arm died of infectious complications ${ }^{16}$. We consider that these authors were not able to show PE efficacy because they studied a set of patients where $P E$ is not usually indicated, namely: (1) patients with recent diagnosis and naïve to any immunosuppressive treatment, (2) initial low doses of CS, and (3) patients with any severity of disease.
In our series, 5/6 patients showed improvement with TPE and no serious adverse effects were reported in these cases. Patient 5 was in septic shock before TPE and remained in septic shock throughout the sessions; infectious complications are one of the major concerns in $\mathrm{PV}$ treated with $\mathrm{TPE}^{16}$. We consider that the lack of infectious adverse events related to PE in our series was due to the specialized and standardized care of the intravenous lines and catheters in our clinic.

Most of the previous reports have followed and manage the number of TPE sessions based on anti-desmoglein titers. Unfortunately, that assay is not available in our center, but our data showed that the number of TPE sessions can be based on clinical improvement.

\section{Conclusion}

TPE associated to immunosuppressive treatment is a safe procedure that has been proved effective in the treatment of refractory cases of $\mathrm{PV}$, it accelerates clinical response and it can contribute in the long-term dose reduction of prednisone. Limitations of our study include its retrospective nature, a small sample size, and a possible reference bias; while our strength is the time of follow-up of the subjects. Although many reports, including ours, suggest that TPE has a role in selected PV cases, additional controlled studies are necessary to confirm these observations. 


\section{Acknowledgments}

AG Colin-Díaz, MI Espinosa-Poblano, A VelazquezGonzalez. Transfusion Medicine Department, Instituto Nacional de Ciencias Médicas y Nutrición Salvador Zubirán

\section{Funding}

This project received no funding.

\section{Conflicts of interest}

The authors declare that does not exist conflicts of interest.

\section{Ethical disclosures}

Protection of human and animal subjects. The authors declare that no experiments were performed on humans or animals for this study.

Confidentiality of data. The authors declare that they have followed the protocols of their work center on the publication of patient data.

Right to privacy and informed consent. The authors declare that no patient data appear in this article.

\section{References}

1. Murrell DF, Peña S, Joly $P$, Marinovic B, Hashimoto T, Diaz LA, et al. Diagnosis and management of pemphigus: recommendations of an international panel of experts. J Am Acad Dermatol. 2020;82:575-85.
2. Brystryn J. Adjuvant therapy of pemphigus. Arch Dermatol. 1984:120:941-51.

3. Brystryn J, Steinman N. The adjuvant therapy of pemphigus-an update. Arch Dermatol. 1996;132:203-12.

4. Murrell DF, Dick S, Ahmed AR, Amagai M, Barnadas MA, Borradori L, et al. Consensus statement on definitions of disease, endpoints, and therapeutic response for pemphigus. J Am Acad Dermatol. 2008:58:1043-6.

5. Porro AM, Filho GH, Santi CG. Consensus on the treatment of autoimmune bullous dermatoses: pemphigus vulgaris and pemphigus foliaceus Brazilian society of dermatology. An Bras Dermatol. 2019;2 Suppl 1:S20-32

6. Harman KE, Brown D, Exton LS, Groves RW, Mahpton PJ, Mustapa MM, et al. British association of dermatologists' guidelines for the management of pemphigus vulgaris 2017. Br J Dermatol. 2017:177:1170-201.

7. Padmanabhan A, Connelly-Smith LA, Balogun R, Klingel R, Meyer E, Pham $\mathrm{H}$, et al. Guidelines on the use of therapeutic apheresis in clinical practice evidence-based approach from the writing committee of the American society for apheresis: the eighth special issue. J Clin Apher. 2019;34:171-354.

8. Turner M, Sutton D, Sauder D. The use of plasmapheresis and immunosuppression in the treatment of pemphigus vulgaris. J Am Acad Dermatol. 2000;43:1058-64.

9. Mazzi G, Raineri A, Zanolli F, Da Ponte C, De Roia D, Santarossa L, et al. Plasmapheresis therapy in pemphigus vulgaris and bullous pemphigoid. Transfus Apher Sci. 2003;28;13-8.

10. Ruocco V, Rossi A, Argenziano G, Astarita C, Alviggi L, Farzati B, et al. Pathogenicity of the intercellular antibodies of pemphigus and their periodic removal from the circulation by plasmapheresis. $\mathrm{Br} \mathrm{J}$ Dermatol. 1978;98:237-41.

11. Auerbach R, Bystryn J. Plasmapheresis and immunosuppressive therapy. Effect on levels of intercellular antibodies in pemphigus vulgaris. Arch Dermatol. 1979;115:728-30.

12. Roujeau J, Andre C, Joneau Fabre M, Lauret P, Flechet M, Kalis B, et al. Plasma exchange in pemphigus. Uncontrolled study of ten patients. Arch Dermatol. 1983;119:215-21.

13. Euler $\mathrm{H}$, Löffler $\mathrm{H}$, Christophers $\mathrm{E}$. Synchronization of plasmapheresis and pulse cyclophosphamide therapy in pemphigus vulgaris. Arch Dermatol. 1987;123:1205-10.

14. Bystryn J. Plasmapheresis therapy of pemphigus. Arch Dermatol. 1988;124:1702-4.

15. Søndergaard K, Carstens J, Zachariae H, The steroid-sparing effect of long-term plasmapheresis in pemphigus: an update. Ther Apher. 1997;1:155-8.

16. Guillaume J, Roujeau J, Morel P, Doutre M, Guillot BLD, Lauret P, et al. Controlled study of plasma exchange in pemphigus. Arch Dermatol. 1988;124:1659-63.

17. Eming R, Sticherling M, Hofmann S, Hunzelmann N, Kern J, Kramer H, et al. S2k guidelines for the treatment of pemphigus vulgaris/foliaceus and bullous pemphigoid. J Dtsch Dermatol Ges. 2017;13:833-44. 